\title{
norden
}

\section{Международный Север}

Международное сотрудничество Совета Министров Северных Стран

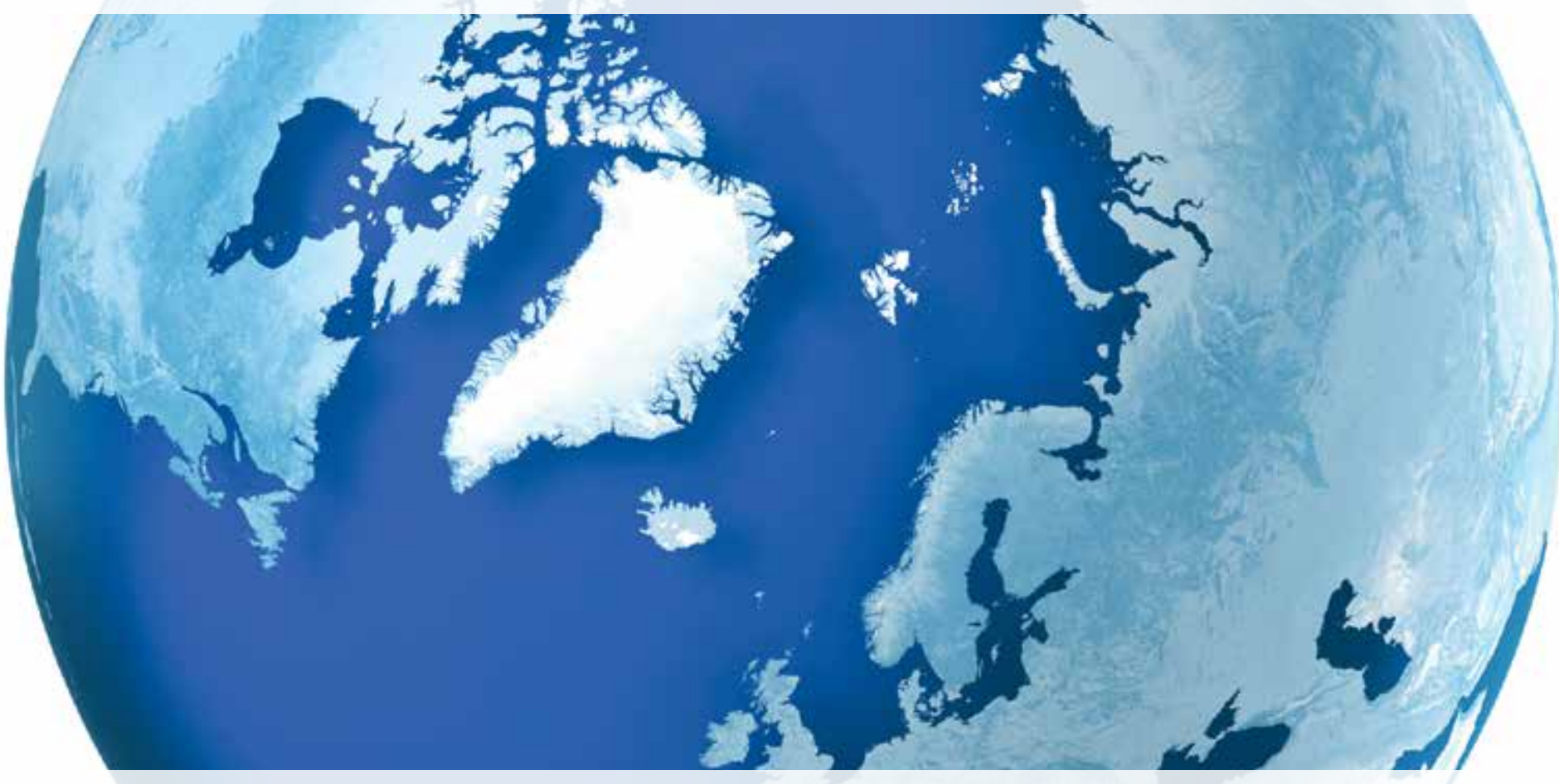




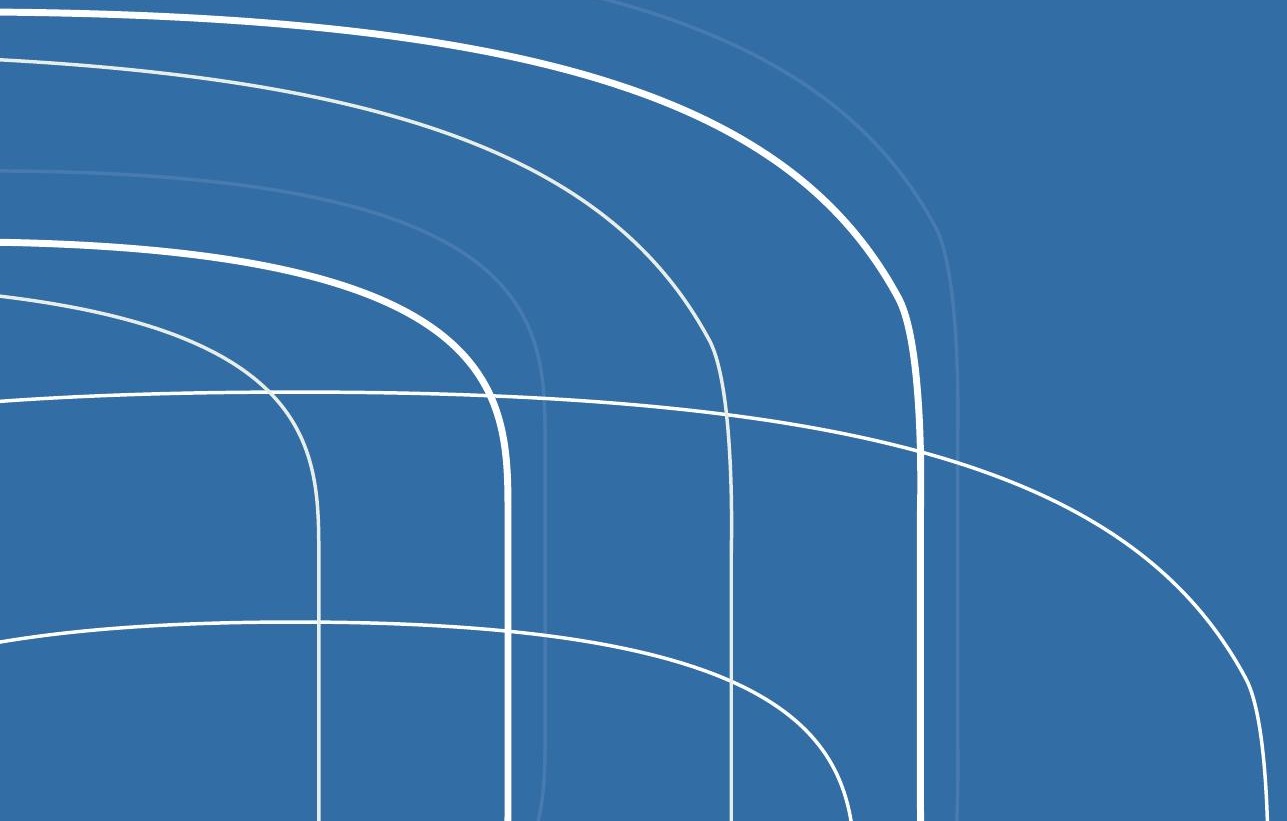




\section{Международный Север}

Международное сотрудничество Совета Министров Северных Стран

Международный Север 5

Эстония, Латвия и Литва 6

Россия

Регион Балтийского моря 13

$\begin{array}{ll}\text { Беларусь } & 14\end{array}$

$\begin{array}{ll}\text { Арктика } & 17\end{array}$

Соседи Северных стран на Западе 18

Северное сотрудничество в мире 19 
Международный Север

Международное сотрудничество Совета Министров

Северных Стран

ISBN 978-92-893-2586-8

http://dx.doi.org/10.6027/ANP2013-754

ANP 2013:754

(C) Совет Министров Северных Стран, Копенгаген 2013

Макет Jette Koefoed

Фотографии: Image Select стр. 12,14-18; Creas стр. 6, 8;

Karin Beate Nøsterud стр. 10; Niels Stern стр. 11;

Nordic-Cool/Trondur-Patursson стр. 19

Фото на обложке: ImageSelect

Бумага: Munken Polar

Шрифт: Meta LF

Тираж: 1000

Печать: Scanprint

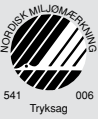

Напечатано в Дании

www.norden.org/publikationer

\section{Северное сотрудничество}

Северное сотрудничество представляет собой одну их самых давних и разнообразных традиций регионального сотрудничества в мире. Это официальное сотрудничество между Данией, Исландией, Норвегией, Финляндией и Швецией, а также Фарерскими островами, Гренландией и Аландскими островами.

Северное сотрудничество охватывает политическое, экономическое, а также культурное взаимодействие, и играет важную роль в европейском и международном контексте. Все Северные страны нацелены на укреплении региона в сильной Европе.

Северное сотрудничество осуществляется на основе общих ценностей и общего стремления к достижению результатов, способствующих динамичному и инновационному развитию, а также повышению потенциала и конкурентоспособности Северных стран в мире.

Совет Министров Северных Стран

Ved Stranden 18

1061 Копенгаген, Дания

тел. +4533960200

www.norden.org 


\section{Международный Север}

Пять Северных стран тесно сотрудничают в Совете Министров Северных Стран. Их сотрудничество основано на общих ценностях, общих традициях и общей истории.

Северные страны также открыты для внешнего мира. С 1990-х годов Совет Министров Северных Стран создал и развил тесное сотрудничество с соседними странами в регионе Балтийского моря. Разрабатывается также сотрудничество в Арктике и сотрудничество с соседями Северных стран на Западе, как, например, с Канадой.
Международное видение Северных стран простирается далеко в окружающий мир, как в страны ЕС, так и глобально.

Совет Министров Северных Стран за многие годы создал обширную международную сеть и имеет большой опыт сотрудничества, как со странами, так и с организациями.

\section{Совет Министров Северных Стран} выделяет около 10 процентов своего годового бюджета, на сотрудничество с соседними странами.
Эта брошюра посвящена прежде всего сотрудничеству Совета Министров Северных Стран с соседними странами, т.е. регионами Балтийского и Баренцева морей, а также Арктикой и соседями на Западе. Вы можете найти более подробную информацию об этом сотрудничестве на различных вебсайтах Совета Министров Северных Стран, ссылки на которые Вы найдете в брошюре.

Приятного прочтения!

\section{Информация:}

Совет Министров Северных Стран (СМСC) - официальный орган межправительственного сотрудничества Северных стран. Премьер-министры Северных стран несут общую ответственность за Северное сотрудничество. На практике ответственность возлагается на министров по делам сотрудничества Северных стран и Комитет по делам сотрудничества Северных стран, которые осуществляют текущую координацию работы. Совет Министров Северных Стран, который был основан в 1971

году, несмотря на свое название, состоит не из одного, а из нескольких советов министров.

Помимо Совета министров по делам сотрудничества, работает еще 10 профильных советов министров. Все советы министров встречаются несколько раз в год. Решения Совета Министров Северных Стран должны приниматься единогласно. Подготовка решений и мониторинг их реализации осуществляются различными официальными комитетами, состоящими из ответственных должностных лиц, представляющих Северные страны.

При Совете Министров Северных Стран имеется целый ряд учреждений и организаций в Северных странах, работающих в различных областях. Например, это Научноисследовательский институт Северных стран (NordForsk) в Осло, Kulturkontakt Nord в Хельсинки, Центр Северных стран по вопросам благосостояния и социального развития (Nordic Welfare Centre) в Стокгольме и многие другие. 


\section{Эстония, Латвия и Литва}

Поддержка Северными странами стран Балтии с конца 1980-х годов и до провозглашения независимости в 1991 году сыграла важную роль в том, что мировое сообщество вскоре признало новый статус стран Балтии в качестве независимых государств. Сотрудничество с Эстонией, Латвией и Литвой остается одним из приоритетных для Северных стран и формализуется в так называемом NB8-сотрудничестве, в которое включены различные министерства. По ряду областей сотрудничества регулярно проводятся встречи министров и ответственных должностных лиц с участием как Северных, так и Балтийских стран.

Совет Министров Северных

Стран имеет офисы в трех балтийских столицах с 1991 года. Офисы играют центральную роль в сотрудничестве между Северными и Балтийскими странами.

\section{Программы мобильности}

Мобильность имеет решающее значение для трансграничного сотрудничества. Это относится как к государственному сектору и бизнесу, так и к искусству и культуре.

\section{В связи с этим Совет} Министров Северных Стран в сотрудничестве с Эстонией, Латвией и Литвой создали ряд совместных программ мобильности для Северных и Балтийских стран, которые направлены на содействие обмену представителей государственного и частного секторов. То же самое относится к представителям искусства и культуры. Путем предоставления финансовой поддержки для учебных визитов, стажировок и сетевых мероприятий, Совет Министров Северных Стран активно участвует в развитии NB8-сотрудничества.

www.kulturkontaktnord.org www.nb8grants.org

\section{Образование}

В сфере образования мобильность и обмен опытом имеют решающее значение. Программа Nordplus Совета Министров Северных Стран предлагает финансовую поддержку сотрудничества в области образования между Северными и Балтийскими странами. Nordplus - это программа как для молодых, так и для пожилых людей, и она может быть использована для установления контактов со всеми, кто заинтересован в этом, в Северных странах и странах Балтии.

www.nordplusonline.org

Офис Совета Министров Северных Стран в Таллине: www.norden.ee

Офис Совета Министров Северных Стран в Риге: www.norden.lv

Офис Совета Министров Северных Стран в Вильнюсе: www.norden.lt 


\section{Офисы Северных Стран}

Сеть офисов Совета Министров Северных Стран в странах Балтии и на Северо-Западе России является уникальной в регионе Балтийского моря. Офисы работают в тесном контакте с органами власти и другими организациями, а также с посольствами и генеральными консульствами Северных стран. Офисы являются катализаторами для развития сотрудничества Совета Министров Северных Стран с соседними странами.

\section{Офисы Совета Министров} Северных Стран:

- Эстония (Таллинн и Тарту)

- Латвия (Рига)

- Литва (Вильнюс)

- Россия (Санкт-Петербург, Калининград, Архангельск, Мурманск и Петрозаводск) 


\section{Россия}

Сотрудничество с Россией, являющейся крупнейшим соседом Северных стран, является особенно важным. История показывает, что развитие, происходящее в России, имеет прямое значение для безопасности и стабильности всего Северного региона, а также для динамичного развития региона Балтийского моря. Поэтому Совет Министров Северных Стран считает одним из своих приоритетов сотрудничество с Россией, и в особенности - с теми регионами Северо-Запада России, которые находятся ближе всего к Северным и Балтийским странам.

Совет Министров Северных Стран имеет Информационные бюро в Санкт-Петербурге и Калининграде, которые были открыты соответственно в 1995 году и 2006 году. Проекты и другие инициативы в рамках сотрудничества Совета Министров Северных Стран с Россией разрабатываются и осуществляются в первую очередь через эти бюро.

\section{В своем сотрудничестве с Россией Совет Министров}

Северных Стран уделяет особое внимание координации

усилий с другими региональными организациями, такими как Арктический совет, Совет Баренцева ЕвроАрктического региона, ХЕЛКОМ и Совет Государств Балтийского моря (СГБМ).

\section{Северное измерение}

В своем сотрудничестве с Россией

Совет Министров Северных

Стран уделяет особое внимание координации усилий с другими региональными организациями, такими как Арктический совет, Совет Баренцева ЕвроАрктического региона, ХЕЛКОМ и Совет Государств Балтийского моря. Совет Министров Северных Стран также активно работает над тем, чтобы вносить свой вклад в так называемое Северное измерение.

Северное измерение представляет собой политическое соглашение между ЕС, Норвегией, Исландией и Россией, принятое в 2006 году. В центре внимания этого политического рамочного соглашения находится сотрудничество в регионах Балтийского и Баренцева морей в целях создания основы для диалога и укрепления экономического сотрудничества, стабильности, конкурентоспособности и устойчивого развития.

www.arctic-council.org www.beac.st www.cbss.org www.helcom.fi 
В рамках Северного измерения создан ряд партнерств,

которые имеют в фокусе, соответственно, окружающую среду, здравоохранение и социальное обеспечение, транспорт и логистику, а также культуру.

Партнерство Северного измерения в сфере культуры было создано по инициативе министров культуры Северных стран, и Совет Министров Северных Стран с 2010 года выполняет функцию секретариата данного партнерства.

Совет Министров Северных Стран, в рамках Партнерства Северного измерения в области общественного здравоохранения и социального благосостояния, участвовал, в том числе, в проектах с Россией, которые содействовали улучшению условий для инфицированных ВИЧ/ СПИД и борьбе против торговли людьми. В рамках Экологического партнерства Северное учреждение NEFCO участвует в целом ряде проектов с Россией, в том числе по энергоэффективности.

www.ndep.org/RUS/index.asp www.ndphs.org

www.ndpculture.org www.ndptl.org/glavnaja 


\section{Россия}

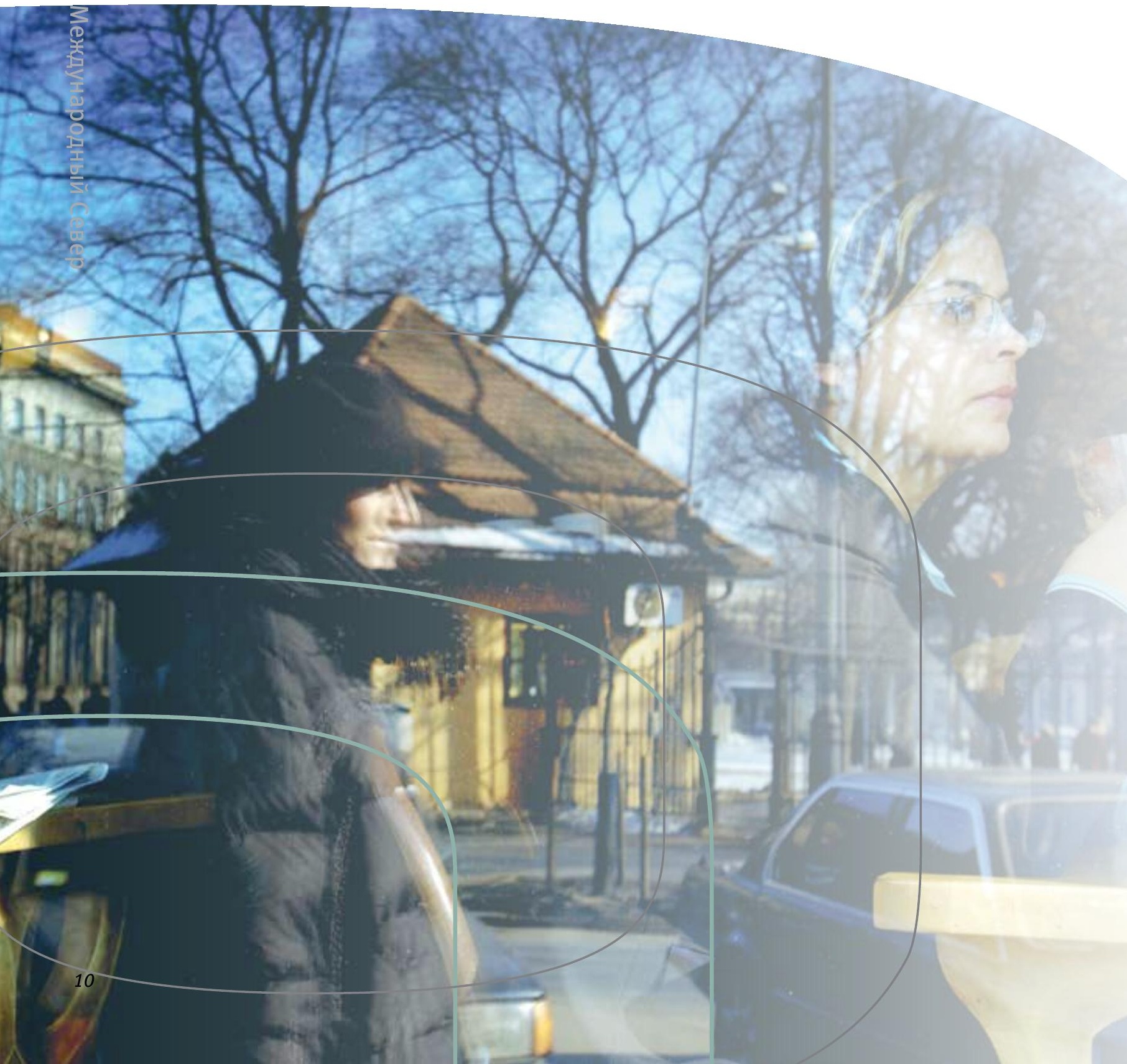




\section{Программы сотрудничества}

Флагманом в сотрудничестве Совета Министров Северных Стран с Россией является Программа повышения уровня компетентности и развития сетевого сотрудничества. Эта программа направлена на повышение уровня знаний и создание партнерских сетей в рамках гражданского общества, образования и науки, экономики и государственного управления на основе обмена опытом и навыками.

Ученые, политики, журналисты и НКО получают возможность участвовать в совместных мероприятиях Северных стран и России, благодаря чему создаются трансграничные сети сотрудничества, которые способствуют укреплению устойчивого и долгосрочного партнерства.

Флагманом в сотрудничестве Совета Министров Северных Стран с Россией является Программа повышения уровня компетентности и развития сетевого сотрудничества.

Информационное бюро Совета Министров Северных Стран в Санкт-Петербурге: www.norden.ru

Информационное бюро в Калининграде: www.norden39.ru

\section{Сотрудничество Северных стран и России в области образования и научных исследований}

В рамках Программы повышения уровня компетентности

и развития сетевого

сотрудничества Совет Министров Северных Стран в 2011 году заключил соглашение о партнерстве с Россией в области высшего образования и науки.

Благодаря этому сотрудничеству, образовательные и научные круги Северных стран и России смогут укрепить свои профессиональные связи и внести общий вклад в решение насущных глобальных проблем в таких областях, как, например, климат и окружающая среда. Партнерство было официально объявлено в январе 2013 года, когда были опубликованы первые сроки подачи заявок по совместным проектам.

www.siu.no/eng 


\section{Регион Балтийского моря}

Совет Министров Северных

Стран сотрудничает с

различными организациями

и форумами сотрудничества

в регионе Балтийского

моря. В их числе - Совет

государств Балтийского моря

(СГБМ), который является

межправительственной

организацией стран Балтийского

региона, Хельсинкская

комиссия (HELCOM), в центре

внимания которой находятся

вопросы окружающей среды

Балтийского моря, и Балтийский

Форум Развития (BDF),

который объединяет деловые

и политические субъекты в

регионе. Совместно со своими

партнерами в Северных странах

и регионе Балтийского моря,

Совет Министров Северных

Стран способствует развитию

и реализации регионального

сотрудничества.

\section{Стратегия региона Балтийского моря}

Европейская Комиссия представила в 2009 году план по расширению сотрудничества в регионе Балтийского моря, так называемую Стратегию региона Балтийского моря с акцентом на охрану окружающей среды, усиление сплоченности и конкурентоспособности. План действий по Стратегии региона Балтийского моря включает в себя ряд проектов в рамках трех основных целей данной стратегии: сохранения Балтийского моря, объединения региона и повышения благосостояния. План действий по Стратегии региона Балтийского моря содержит ряд флагманских проектов, и впервые такая всеобъемлющая стратегия была подготовлена для всего региона в рамках ЕC.

Приоритеты Стратегии региона Балтийского моря и Совета Министров Северных Стран совпадают. В связи с этим Совет Министров Северных Стран активно участвует в реализации проектов, используя свою сеть сотрудничества в Северных странах и регионе Балтийского моря. Через организацию дебатов, реализацию проектов и другие инициативы, Совет Министров Северных Стран помогает обеспечить важное место Стратегии региона Балтийского моря в политической повестке дня.

Совет Министров Северных Стран считает важным, чтобы российские партнеры участвовали в проектах в рамках Стратегии региона
Балтийского моря, хотя Россия и не включена в эту стратегию. Поэтому Совет Министров Северных Стран поддерживает проекты с участием российских партнеров, которые обеспечивают их вовлечение в крупные региональные проекты, финансируемые ЕС.

www.cbss.org

www.helcom.fi

www.bdforum.org

www.balticsea-region-strategy.eu

\section{Общественные организации}

Совет Министров Северных Стран считает, что общественные организации играют важную роль в сотрудничестве в регионе Балтийского моря. В связи с этим Совет Министров Северных Стран с 2006 года реализует Программу по сотрудничеству с НКО для региона Балтийского моря, которая поддерживает сотрудничество между НКО в Северных странах и странах Балтии, России, Беларуси и Польше. Программа НКО направлена на то, чтобы обеспечить возможность общественным организациям влиять на деятельность в регионе. Общая цель программы - поддерживать продвижение 
гражданского общества и укрепление трансграничного сотрудничества, обеспечивая тем самым вклад в развитие региона.

www.norden.org/ngo-balticsearegion

\section{Профильные советы} министров и учреждения Совета Министров Северных Стран целенаправленно работают над осуществлением Стратегии региона Балтийского моря. В рамках этой работы Совет Министров Северных Стран способствует осуществлению Плана действий по Стратегии региона Балтийского моря в ряде своих проектов. Это касается, например, таких областей, как лесное хозяйство и предотвращение распространения заболеваний домашнего скота. Согласно последней версии Плана действий, Совет Министров Северных Стран берет на себя ответственность за развитие сотрудничества в сфере биоэкономики, а также в сфере культуры, с особым акцентом на устойчивое развитие. 


\section{Беларусь}

Беларусь граничит с Латвией, Литвой и Россией, и Северные страны имеют естественный интерес к содействию развитию свободы слова, толерантности, равноправия и демократии в регионе.

Совет Министров Северных Стран намерен способствовать демократизации общественного развития в Беларуси путем оказания поддержки гражданскому обществу и сотрудничества с ним, а также, где это возможно, с местными и региональными властями.

Целью Совета Министров Северных Стран является координация деятельности в Беларуси с двусторонними инициативами Северных стран, а также другими инициативами, направленными на достижение максимально возможного синергетического эффекта.

\section{С 2005 года Совет Министров Северных стран в}

сотрудничестве с Европейской Комиссией поддерживает белорусский университет, который находится в изгнании в Вильнюсе, - Европейский Гуманитарный Университет (ЕГУ).

В практической реализации деятельности по Беларуси Совет Министров Северных Стран работает в тесном партнерстве с Европейской Комиссией.

\section{Европейский Гуманитарный Университет}

С 2005 года Совет Министров Северных стран в сотрудничестве с Европейской Комиссией поддерживает белорусский университет, который находится в изгнании в Вильнюсе, Европейский Гуманитарный Университет (ЕГУ). Университет открылся в Минске в 1992 году и стал первым белорусским университетом, в котором были внедрены европейские стандарты и методики в области высшего образования. После сильного давления со стороны белорусских властей, стремившихся изолировать систему образования от международного влияния, университет был закрыт в 2004 году. Через год университет вновь открыл свои двери в соседней Литве, а в 2006 году получил статус частного литовского университета.

Университет предоставляет примерно 2000 молодых 
белорусов доступ к свободному и открытому высшему образованию. Для студентов и сотрудников ЕГУ во многих случаях учеба и работа в университете связана с персональным риском преследований и притеснений со стороны белорусских властей, что лишь подчеркивает необходимость поддержки университета, который возможно однажды сможет вернуться в Беларусь, $и$ будет способствовать демократическому развитию в стране.

Финансирование университета обеспечивается за счет Трастового фонда ЕГУ, основанного Советом Министров Северных Стран и Европейской Комиссией в 2008 году. Администрирование Фонда осуществляется Советом Министров Северных Стран, что обеспечивает эффективное и прозрачное управление средствами ЕГУ.

www.ehu.It

www.ehutrustfund.org

\section{Стипендиальная программа «Открытая Европа»}

Стипендиальная программа «Открытая Европа» (OESS) финансируется Европейской Комиссией и управляется Советом Министров Северных Стран. Молодые белорусы, которые отвечают академическим, языковым и персональным требованиям, могут подавать заявки на стипендию для получения высшего образования в Европе - без идеологических предрассудков и в соответствии с международными академическими стандартами. ЕС и Совет
Министров Северных Стран видят цель программы в том, чтобы получатели стипендии после завершения образования смогли вернуться к себе домой, усилив свои компетенции, связанными с поддержкой будущего демократического развития Беларуси.

www.oess.eu

\section{Стабильность гражданского общества Беларуси}

Совет Министров Северных Стран осуществляет управление проектом «Стабильность гражданского общества Беларуси» (CSSB), который поддерживает гражданское общество в Беларуси после президентских выборов в 2010 году. Инициатива финансируется Европейской Комиссией в целях оказания помощи жертвам, пострадавшим от вмешательства властей, организациям гражданского общества и независимым средствам массовой информации.

www.cssb.lt 


\section{Арктика}

Арктика - это область, где имеется и необходимость, и возможности для динамичного развития. Изменение климата, новые морские пути, растущие потребности в энергии в глобальном масштабе и развитие новых технологий делает возможным восстановление ресурсов в суровых арктических условиях.

Глобальные изменения климата оказывают существенное давление на природу и население Арктики. Средняя температура в Арктике растет, и таяние ледников и морского льда открывают наличие природных ресурсов в регионе. Все это имеет последствия для природы, общества и населения Арктики, но также открывает и новые возможности. Большая часть суши и морских районов Северных стран расположена в Арктике, поэтому проблемы Арктики находятся в центре внимания Северных стран.

Северные страны считают, что при использовании новых возможностей, которые открываются в Арктике, необходимо с уважением относиться к природе и окружающей среде. В то же время необходимо обеспечивать условия жизни и развитие населения Арктики. Развитие современного государства всеобщего благосостояния находится в центре внимания. В программе арктического сотрудничества пяти Северных стран приоритетом является окружающая среда и в особенности люди, живущие в регионе.

\section{Арктический совет}

Все Северные страны являются членами Арктического совета, наряду с Канадой, Россией и США. Совет Министров Северных Стран выполняет функцию наблюдателя в Арктическом Совете с тех пор, как он был создан в 1996 году. Совет Министров Северных Стран работает также в тесном сотрудничестве с другими региональными советами, такими как Совет Баренцева ЕвроАрктического региона, в целях достижения открытости и создания сетевого сотрудничества в Арктике. Совет Министров Северных Стран финансирует ряд проектов и мероприятий в Арктике посредством программы арктического сотрудничества Северных стран. Кроме того, профильные сектора и учреждения Совета Министров Северных Стран, такие как NordForsk, Nordregio и NORA, ведут обширную деятельность в Арктике.

www.arctic-council.org

Все Северные страны являются членами Арктического совета, наряду с Канадой, Россией и США. Совет Министров Северных Стран выполняет функцию наблюдателя в Арктическом Совете с тех пор, как он был создан в 1996 году. 


\section{Соседи Северных стран на Западе}

Сотрудничество между Советом Министров Северных Стран и соседями Северных стран на Западе в последние годы укрепилось. Соседями на Западе являются Канада, США, Ирландия и Шотландия. Северные страны, Гренландия и Фарерские острова, вместе со своими западными соседями, стоят перед многими общими задачами, такими как наличие малонаселенных районов, большие расстояния, холодный климат и большая зависимость от моря и морских ресурсов. Новые морские пути Арктике влияет на геополитические интересы и стратегическое значение региона. Это создает новые вызовы и возможности для соседних Северных и СевероАтлантических областей.

\section{Сотрудничество между}

Северными странами в рамках Совета Министров Северных Стран и соседями на Западе является многосторонним и осуществляется в тех областях, где есть место Северным ценностям. Это сотрудничество дополняет двустороннее сотрудничество Северных стран с соседями на Западе. Организация сотрудничества Северного и Атлантического регионов (NORA) является органом сотрудничества
Северных стран с опытом сотрудничества с Северной Атлантикой.

Основные направления сотрудничества Совета Министров Северных Стран с соседями на Западе уделяют особое внимание сотрудничеству в следующих областях:

- Морской регион

- Промышленность, окружающая среда, климат и энергетика

- Образование, исследования и инновации

- Культура

- Здоровье

\section{Сотрудничество между Советом Министров Северных Стран и соседями Северных стран на Западе в последние годы укрепилось. Соседями на Западе являются Канада, США, Ирландия и Шотландия.}




\section{Северное сотрудничество в мире}

Интерес к Северному

сотрудничеству в мире растет в

связи с ростом глобализации.

Совет Министров Северных Стран

на различных уровнях активно

участвует в процессе укрепления совместных усилий Северных стран во всем мире. В качестве примера можно упомянуть, что Северное сотрудничество используется в качестве модели на Балканах, где должны быть созданы новые структуры для межправительственного сотрудничества. В Азии Совет Министров Северных Стран сотрудничает с "Трехсторонним Секретариатом" - организацией сотрудничества Китая, Южной Кореи и Японии. Также не в последнюю очередь стоит упомянуть о том, что крупная инициатива Северных стран "Nordic Cool” в Центре Кеннеди в Вашингтоне в 2013 году оказалась очень ценной. Интерес к Северному сотрудничеству в мире стремительно растет.

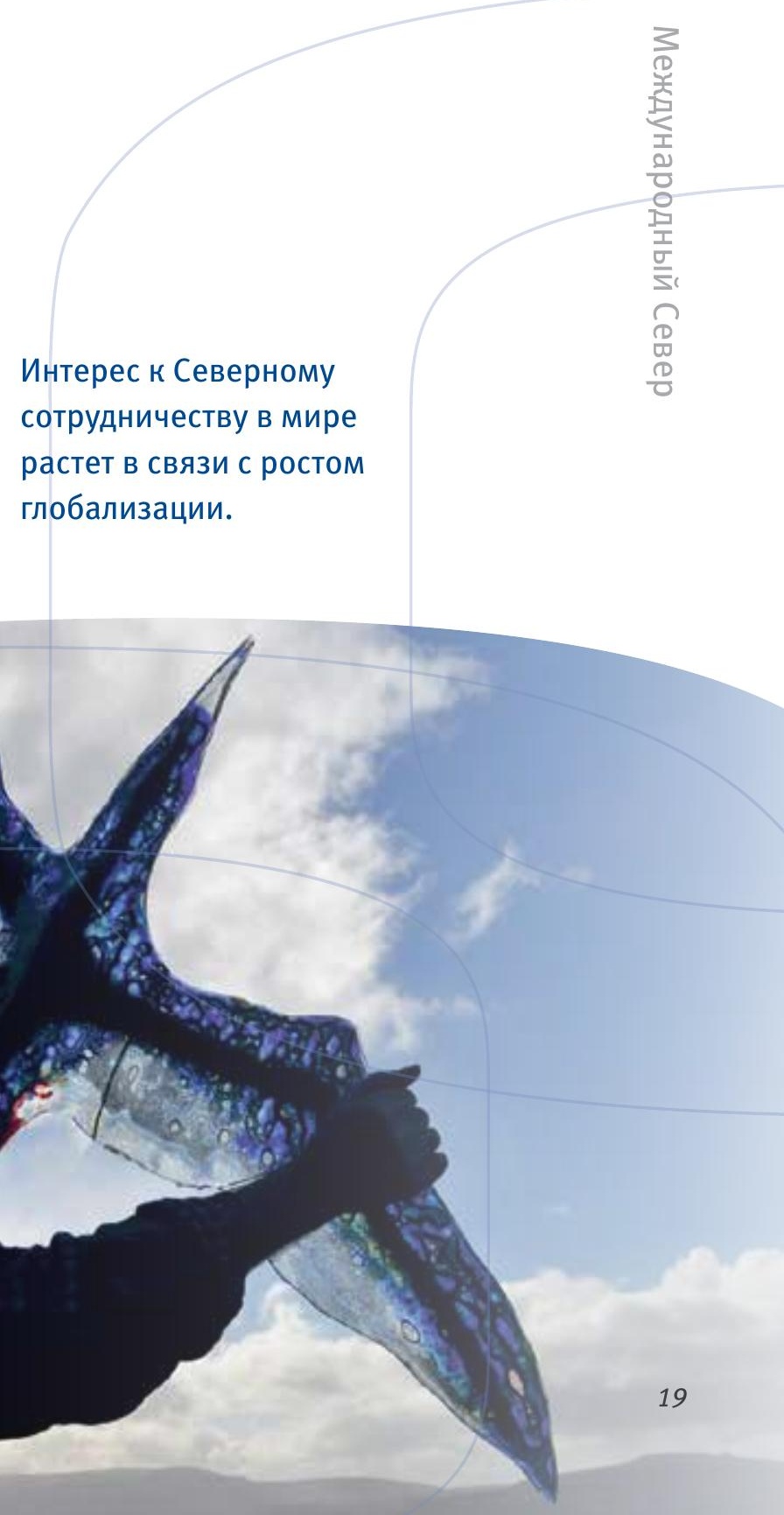




\section{nordon}

\section{Nordisk Ministerråd}

Ved Stranden 18

DK-1061 København K

www.norden.org

\section{Международный Север}

Эта брошюра посвящена прежде всего сотрудничеству Совета Министров Северных Стран с соседними странами, т.е. регионами Балтийского и Баренцева морей, а также Арктикой и соседями на Западе. Вы можете найти более подробную информацию об этом сотрудничестве на различных вебсайтах Совета Министров Северных Стран, ссылки на которые Вы найдете в брошюре.

ANP 2013-754

ISBN 978-92-893-2586-8 